\title{
European Union policy-making towards Mercosur
}

\section{Introduction}

The EU is not a state and is not a traditional international organization. It is common to characterize it as a hybrid system with a federal component, but nothing comparable exists at this point in time. To understand EU policy-making towards Mercosur it is important to understand the internal system of the EU, its internal policy-making and the internal system of Mercosur, particularly given that Mercosur has tried to replicate the institutional design of the EU.

Since its creation in 1957 in the Treaty of Rome, the EU has changed dramatically in a variety of ways in a short period of time. The discussion here will examine these changes over the period between 1985 and 2015. It is also important to note that the number of EU member states has quadrupled since it was created in 1957. It could be argued that this has resulted in a decline in the power held by each individual member state. In 1986 Spain and, to a lesser extent, Portugal brought a Mediterranean influence into EU politics. This was later balanced out by further enlargement in 1995 which saw Austria, Finland and Sweden joining the EU. However, the single largest enlargement in the history of the EU took place in 2004 when ten Central and Eastern Europe countries became EU members. From 1989 until the enlargement in 2004, the end of the Cold War and the breakup of the Soviet Union into several independent republics had been the main focus EU external relations, to the point that it had an effect on other external relations, including external relations with Latin America. The enlargement of the EU in 2007 is not discussed in any detail here because it did not have an impact on the EU policy towards Mercosur.

The Treaty of Rome introduced legal frameworks that would inform the creation of EU policies. Since then, the EU has introduced further new treaties which have modified these legal foundations. These changes will be discussed here because they have played a crucial role in terms of affecting 
policy-making and/or decision-making procedures. The Single European Act of 1986 was crucial because it brought changes to policy-making in the area of EU external relations. However, it was the Treaty of Maastricht in 1992 that brought some of the most important policy changes in external relations. In contrast, changes incorporated by the 1997 Treaty of Amsterdam, the 2001 Treaty of Nice and the 2009 Treaty of Lisbon did not alter EU policy-making towards Mercosur. It should be noted that the term EU is used consistently throughout, in an attempt to avoid the confusion that would arise from the use of European Community or European Union, depending on whether the discussion concerns pre- or post-Maastricht events.

\section{EU policy-making towards Mercosur}

EU policy towards Mercosur is a key part of the EU's more general policy towards Latin America. It could be argued that for many years EU policy towards Mercosur was in fact the most important part of EU policy in the region, and the following section contextualizes this by briefly discussing EU policy towards Latin America. At this point, however, it should be acknowledged that EU policy towards Mercosur involves a mixture of trade, cooperation and association agreements. Therefore, it is important to start this study by looking at those agreements, especially since they provide the legal framework, and consequently the internal rules, for both policy-making and decision-making. This outline of the introduction of the legal framework is followed by a discussion of policy-making processes. This will enable us to develop a greater understanding of the sequence of events which occurred during the course of those agreements. The final section of the first part of this chapter will provide an analytical account of the various roles of the actors involved in the creation of trade, cooperation and association agreements, particularly the nature of their interactions with one another. This will help us to understand how different actors have different types of room for manoeuvre, whilst acknowledging that the EU Commission and the EU Council are the most important actors because they have most of the power when developing these types of policies.

First, however, it is necessary to explain why the EU prioritized Mercosur for a period of time, particularly since the study of EU-Latin American relations overlaps the study of EU-Mercosur relations for some of the time-frame. Until 1995, the overlapping of EU-Latin American relations and EU-Mercosur relations was so significant that it could be considered to be the interchangeable, or at least the most important feature of EU-Latin America relations, as explained in the previous chapter.

During the 1980s, the EU was an exceptional witness through the EU-Rio Group meetings of Mercosur advances in regional integration which gained momentum in 1985 with Argentina and Brazil signing their first agreement. 
With that agreement, Argentina and Brazil played a fundamental role in terms of developing a project that would promote regional integration in Latin America. The first EU-Mercosur inter-institutional cooperation agreement was reached in 1992. Through this agreement the EU provided technical help such as know-how. The following year, the EU and Mercosur considered a further upgrading of their relations once Mercosur was a customs union, and in 1995 the framework for the negotiation of an association agreement between the EU and Mercosur came into force as Mercosur became such a union (albeit an imperfect one). Basically, EU policy-making increased over time and through these different agreements.

\section{Political process}

EU policy, according to Wallace and Young, is:

a kaleidoscope of changing patterns of participation in the collective process of European policy-making on issues of market regulation and policies for industry. Participation in the European arena constitutes a shift in two dimensions. First, the European policy model marks a distinct departure from patterns of policy-making in national arenas. Second, the European policy process is in flux, varying between policy areas and over time. (Wallace and Young 1997: 235)

In order to explain the different aspects of this kaleidoscope, it is useful to look at the political system in both its horizontal and vertical aspects. In terms of the vertical separation of powers, it was noted at the beginning of this chapter that the EU could be described as a form of federal system. At the time of its creation, the transfer of power from individual nation states to the European 'government' was carried out in a series of phases rather than in one single transfer. This was designed to minimize the opposition from the national governments that Jean Monnet had anticipated (Pollack 2005: 28). Trading policy was transferred to the EU straightaway. In contrast, powers that related to international security policy remained in the hands of individual member states. The fact that this is still the case today explains why certain agreements with Mercosur are negotiated by the Commission - who have been responsible for dealing with matters of trade policy since the Treaty of Rome - and why other matters are negotiated by the Commission and the national states' representatives. The distribution of power between the EU and its member states resembles a federal system in many ways (Pollack 2005). However, Pollack (2005) argues that the way that this is expressed in such vague language implies that most policy areas are dealt with at both the national and the supranational levels. The vague nature of this institutional arrangement enables the European Court of Justice to clarify the limitations that are not established in the Treaties. Consequently, whenever there is disagreement, the European Court of 
Justice will decide who - according to the treaties - should have a further increase in their competence in that specific area. In other words, when there is a disagreement between the states and the Commission, the European Court of Justice will have the final say.

As well as the vertical separation of powers in the EU, there is the horizontal separation of powers in the EU. The legislative system is often referred to as a bicameral system. The agenda-setter in this system is the Commission, although the legislative powers of the European Parliament (EP) have been growing since the 1980s (Pollack 2005). However, as will be demonstrated in the discussion below, the EP has no real powers in terms of influencing EU-Mercosur relations and policy development. In relation to these matters, the most significant institutional arrangement is the relationship between the Commission and the Council, especially if the Commission is seen as an agenda-setter: 'Deciding what to decide is a crucial part of the policy-making process and one that often takes place in a context where there is a great deal of uncertainty. Deciding what to decide actually involves two steps in the policy cycle: agenda-setting and policy formation' (Young 2010: 115).

The agenda is set through a series of pre-selection of issues or debate about alternatives before a particular policy is chosen and before the discussion moves on to the actual formulation of policy. This is crucial in terms of understanding not only how some policies actually go ahead, but also why some policies are not taken forward. To a certain extent, this can also be influenced by hidden political reasons. During the process of pre-selection, the Commission has considerable power. In October 1994, the Commission produced a document which elaborated on the possible scenarios and options that were available to the EU in relation to upgrading EU-Mercosur relations. At that particular moment in time, the Commission could have included other issues: for example, the Commission could have developed other major and/or more specific ways in which it could have become involved in the political side of EU-Mercosur relations. This, however, was not the case, possibly because the Commission was aware that this could lead to future problems in terms of the relations between the Commission and the Council of Ministers further down the road. In summary, the Commission does not have absolute power in relation to preparation of documents and proposals, and therefore the Commission must consider in advance how its proposals will be received by the Council.

Policy formulation also attracts other actors who are not involved in the agenda-setting (Young 2010). This is interesting in the sense that it demonstrates just how influential the Commission has been when preparing the policy-making agenda. Irene Bellier contends that:

European civil servants are the first to recognize the influence of pressure groups over certain items of European legislation (notably directives), but they tend to be most conscious of the role of national negotiators and the way 
they are able to promote the preferences of large national consortia from farming, industry, and financial services. It is a hard distinction to pin down if we want to assess the patterns of influence; it requires us to distinguish between the factors that belong to the policy process and those which arise from the operation of markets. (Bellier 1997: 108)

The European business associations with interests in Mercosur were in favour of the association agreement between the EU and Mercosur and asked for a liberalization of the markets of both Mercosur and the EU. What is not clear is whether the Commission considered the liberalization of the markets in its October 1994 proposal to upgrade EU-Mercosur relations as a result of any pressure from the business associations or whether this was simply due to the EU's general support of opening up markets in other countries. It could be argued that the Commission was influenced by the business associations because the 1995 agreement included a free trade agreement. However, it should be noted that the Commission's general agenda also promoted free trade. Interestingly, other sectors such as agriculture also lobbied the Commission in order to express their opposition to a free trade agreement and in the end words such as 'free trade' were taken out of the Council directives passed to the Commission for the negotiation of the agreement. The claim that the Commission was influenced needs substantive evidence in order to carry any weight. Furthermore, Bellier claims that

There is a fine line between giving out information on its plans, to which the Commission puts up little resistance, and allowing influence over which options are chosen: but it is here than the distinction is drawn between a decision to promote an overall European interest and the satisfaction of narrower concern, whether national or private. (Bellier 1997: 108)

The bottom line is that the Commission has a key role to play, both in setting the policy-making agenda and in the actual process of policy formulation. This gives the Commission a great deal of power in terms of shaping EU policies (Young 2010). In the area of executive politics, the rational-choice and principal-agent analyses are the dominant approaches in the existing literature (Pollack 2005; Young 2010).

The Commission can take a different course of action from that expected by member states. This was already suggested above when discussing whether or not the Commission can be influenced by other actors when creating a policy agenda. Obviously the Commission may have its own 'ambitions' or ideas that it might try to develop within the region. In relation to EU-Mercosur relations, the Commission has demonstrated a degree of interest in Mercosur and has, therefore, tried to reach an agreement with the Council. It is also clear that not all members of the Commission or the Council agreed with the policy towards Mercosur. Nevertheless, an agreement was reached. However, some states felt that the 
Commission had gone too far and there was a discussion about the Commission's proposal in the Council at the time when the directives were being prepared in the Council for the Commission.

\section{The EU's legal basis}

In relation to the legal basis for EU agreements with other regions or countries, the use of one or other article implies a different division of power in the areas of policy and decision-making. This does not mean that different types of EU agreements are completely separate from each other and cover entirely different policies in practice. They are different mainly in the sense that different legal frameworks are used according to the type of agreement. The main types of agreements are trade, cooperation or development cooperation and association (Nugent 2003; Smith 2003). The Common Commercial Policy (CCP) since the Treaty of Rome provides the basis for economic agreements. Article 133 is the first legal framework involved when developing economic agreements. However, the creation of trade agreements in isolation from other types of agreement is in fact quite rare because simple economic agreements are somewhat limited and there are other types of agreements which tend to be favoured by third parties (Smith 2003). Therefore, Article 133 tends to be used in conjunction with other articles in order to reach a combination of trade and economic cooperation agreements or association agreements.

It is also common for trade and economic cooperation agreements to be developed under Articles 133 (CCP) and others such as Article 181 (ex $130 y$ ) and 300 (ex 228): 'For example, in the case of trade agreements with developing countries, Articles 177 and 181, which are related to development matters, could be employed as part of the legal basis of trade negotiations which are designed to create preferential trade agreements' (Aggarwal and Fogarty 2004: 28).

As this study focuses on policy development between 1985 and 2007, it tends to be the 1992 Maastricht Treaty, alongside other subsequent changes in the EU's legal framework, which form the legal basis for developing agreements. For example, the 1995 EMIFCA continues to be the basis for EU-Mercosur relations today. This agreement was formulated after the Maastricht Treaty. Boxes 3.1 and 3.2 provide an overview of the official text related to the articles that are involved when developing EU agreements with Mercosur. Boxes 3.1 and 3.2 also include changes that emerged when developing new treaties.

In the case of EU-Mercosur policy, the legal basis for the agreement signed in 1995 was Articles 133, 181 and 300. Furthermore, association agreements are covered by Article 310 (ex 238). These are outlined in Boxes 3.1, 3.2 and 3.3. Since different agreements create different divisions of labour in terms of policy-making and decision-making, the various actors 


\section{Box 3.1 Article 133 (ex Article 113)}

1. The common commercial policy shall be based on uniform principles, particularly in regard to changes in tariff rates, the conclusion of tariff and trade agreements, the achievement of uniformity in measures of liberalisation, export policy and measures to protect trade such as those to be taken in the event of dumping or subsidies.

2. The Commission shall submit proposals to the Council for implementing the common commercial policy.

3. Where agreements with one or more States or international organisations need to be negotiated, the Commission shall make recommendations to the Council, which shall authorise the Commission to open the necessary negotiations.

The Commission shall conduct these negotiations in consultation with a special committee appointed by the Council to assist the Commission in this task and within the framework of such directives as the Council may issue to it.

The relevant provisions of Article 300 shall apply.

4. In exercising the powers conferred upon it by this Article, the Council shall act by a qualified majority.

5. The Council, acting unanimously on a proposal from the Commission and after consulting the European Parliament, may extend the application of paragraphs 1 to 4 to international negotiations and agreements on services and intellectual property insofar as they are not covered by these paragraphs.

Amendments included in the Treaty of Nice:

This article was amended by the Nice Treaty to extend the scope of commercial policy and, as a result, of qualified majority voting for agreements in the fields of trade in services and the commercial aspects of intellectual property. There are still, however, some exceptions to this principle:

- The Council may not conclude agreements which entail harmonisation of national legislation in fields such as culture, education or human health (fields in which the Community does not have internal powers of harmonisation);

- The Council must act unanimously where the agreement includes provisions for which unanimity is required for the adoption of internal rules (parallelism) or where it relates to a field in which the Community has not yet exercised its internal powers;

- This article does not apply to the field of transport.

Source: European Communities (2002). 


\section{Box 3.2 Article 181 (ex Article 130y)}

Within their respective spheres of competence, the Community and the Member States shall cooperate with third countries and with the competent international organisations. The arrangements for Community cooperation may be the subject of agreements between the Community and the third parties concerned, which shall be negotiated and concluded in accordance with Article 300.

The previous paragraph shall be without prejudice to Member States' competence to negotiate in international bodies and to conclude international agreements.

Source: European Communities (2001).

\section{Box 3.3 Article 300 (ex Article 228)}

1. Where this Treaty provides for the conclusion of agreements between the Community and one or more States or international organisations, the Commission shall make recommendations to the Council, which shall authorise the Commission to open the necessary negotiations. The Commission shall conduct these negotiations in consultation with special committees appointed by the Council to assist it in this task and within the framework of such directives as the Council may issue to it.

In exercising the powers conferred upon it by this paragraph, the Council shall act by a qualified majority, except in the cases where the first subparagraph of paragraph 2 provides that the Council shall act unanimously.

2. Subject to the powers vested in the Commission in this field, the signing, which may be accompanied by a decision on provisional application before entry into force, and the conclusion of the agreements shall be decided on by the Council, acting by a qualified majority on a proposal from the Commission. The Council shall act unanimously when the agreement covers a field for which unanimity is required for the adoption of internal rules and for the agreements referred to in Article 310. 


\section{Box 3.3 Article 300 (ex Article 228)—cont'd}

By way of derogation from the rules laid down in paragraph 3, the same procedures shall apply for a decision to suspend the application of an agreement, and for the purpose of establishing the positions to be adopted on behalf of the Community in a body set up by an agreement based on Article 310, when that body is called upon to adopt decisions having legal effects, with the exception of decisions supplementing or amending the institutional framework of the agreement.

The European Parliament shall be immediately and fully informed on any decision under this paragraph concerning the provisional application or the suspension of agreements, or the establishment of the Community position in a body set up by an agreement based on Article 310.

3. The Council shall conclude agreements after consulting the European Parliament, except for the agreements referred to in Article 133(3), including cases where the agreement covers a field for which the procedure referred to in Article 251 or that referred to in Article 252 is required for the adoption of internal rules. The European Parliament shall deliver its opinion within a time-limit which the Council may lay down according to the urgency of the matter. In the absence of an opinion within that time-limit, the Council may act.

By way of derogation from the previous subparagraph, agreements referred to in Article 310, other agreements establishing a specific institutional framework by organising cooperation procedures, agreements having important budgetary implications for the Community and agreements entailing amendment of an act adopted under the procedure referred to in Article 251 shall be concluded after the assent of the European Parliament has been obtained. The Council and the European Parliament may, in an urgent situation, agree upon a time-limit for the assent.

4. When concluding an agreement, the Council may, by way of derogation from paragraph 2, authorise the Commission to approve modifications on behalf of the Community where the agreement provides for them to be adopted by a simplified procedure or by a body set up by the agreement; it may attach specific conditions to such authorisation. 


\section{Box 3.3 Article 300 (ex Article 228)—cont'd}

5. When the Council envisages concluding an agreement which calls for amendments to this Treaty, the amendments must first be adopted in accordance with the procedure laid down in Article 48 of the Treaty on European Union.

6. The Council, the Commission or a Member State may obtain the opinion of the Court of Justice as to whether an agreement envisaged is compatible with the provisions of this Treaty. Where the opinion of the Court of Justice is adverse, the agreement may enter into force only in accordance with Article 48 of the Treaty on European Union.

7. Agreements concluded under the conditions set out in this Article shall be binding on the institutions of the Community and on Member States.

Source: European Communities (1997).

hold different levels of power, reflected in the types of decision rules that apply to each of them, according to the different potential scenarios.

Over the years, there have been several changes to the treaties in relation to the EU's legal framework and there have also been corresponding modifications to the division of powers. In relation to the CCP, further legal specification was necessary over the years in response to the development of trade in different areas such as services or intellectual property and their importance at international level. In other words, trade became more interconnected. In the 1990s, the Commission started to put pressure on individual EU member states to expand the framework of Article 133 to include the trade of services and intellectual property (Nugent 2003: 410). In 1994, the European Court of Justice decided that there should be a degree of shared responsibility between the EU and the member states. This matter was not resolved by the Treaty of Amsterdam in 1997 but was, to a certain extent, addressed in the Treaty of Nice. As a result of this treaty, trade in services became an exclusive competence of the Commission, although in some areas it required unanimity and some issues were excepted (Nugent 2003: 410). However, trade issues continued to produce a degree of controversy, particularly issues that were related to environmental and labour standards (Smith 2003: 34-35).

With regard to external agreements, it is also common for Article 300 to be used. In addition to this, there is a tendency for Article 181 to be used because it is specifically designed for matters relating to the development of cooperation (Nugent 2003). Over time, trade and cooperation agreements can include many issues which have previously not been thought possible 
either because of the lack of development of EU external relations or because of the situation of the third parties. Therefore, it is common for policy development to begin with a simple agreement that is subsequently further developed or upgraded with the intention of developing free trade agreements, or to include, for example, certain political conditions such as human rights, which has been the case since the 1980s (Nugent 2003).

In terms of association agreements, it has already been noted that different types of political agreements bring different conditions. Association agreements are a specific kind of agreement that is produced with particular countries or regions in mind. In some cases they are produced in regard to those preferred countries that will become members of the EU in the future. These agreements are developed in relation to Article 310 (ex Article 238). This was noted by Nugent, who claims that 'The Community may conclude with one or more states or international organisations agreements establishing an association involving reciprocal rights and obligations, common action and reciprocal procedure' (Nugent 2003: 411).

In the case of EU-Mercosur relations, the ongoing negotiations, which include a free trade agreement, are part of an association agreement that was launched in 1999. As will be explained in the next section, association agreements require unanimity among the member states, and the approval of the EP granted by a majority vote before they can become official (Woolcock 2005). Association agreements also include trade issues and in some cases they can encompass aid from the EU and loans from the European Investment Bank (EIB). In these instances, agreements will establish an association council consisting of a minister from either side who will come together to discuss common issues (Smith 2004: 55). This demonstrates that association agreements have a different, if not higher, level of political meaning from agreements which are designed to facilitate interregional cooperation. The different decision-making procedures are explained in the following section.

\section{Policy processes}

The policy process for creating trade agreements under Article 133 is different from the policy process that is followed when creating association agreements. The Commission considers the option of a trade agreement with a third party; then the Commission seeks to receive a mandate from the Council. This is done by gaining a recommendation from the General Affairs and External Relations Council. After that, the Committee of Permanent Representatives (COREPER) of the Council works on this recommendation and passes it to the Council. At this point, the Council can modify the directives or guidelines with the help of COREPER, and if the Council fails to reach an agreement a decision is reached using the qualified 
majority voting (QMV) rule. Once a mandate has been secured, the Commission will lead the negotiations. Different members such as commissioners and director generals can intervene in the negotiations. For example, the commissioners and director generals of agriculture, development and/or trade can intervene in these negotiations. The degree of freedom that the Commission has to negotiate on behalf of the EU depends on each case, linked to the different positions of different member states on that issue (Nugent 2003: 413). Some countries will favour protectionism, whilst others will favour free trade, and therefore the Commission's flexibility is limited. However, the Commission can use this situation as a spur for negotiation and can blame the Council for deals that they do not want to accept (Nugent 2003: 413). Moreover, the Council monitors the negotiations through a committee, as specified in Article 133. This committee is composed of officials from individual EU member states and ministries and meets frequently. The committee can even modify the mandate, but if the mandate relates to a sensitive issue the final decision will be made by the COREPER or the Council (Nugent 2003: 413). Once the agreement has been fully negotiated with the third party, the next step is to pass it to the Council for approval or rejection.

Therefore, it is important to examine why the Council, as part of an association agreement, would delegate the negotiation of an FTA with Mercosur to the Commission. In relation to this agreement we should also consider whether these directives were ambitious. In this instance, it is possible that the Commission would try to go further than the Council wanted in terms of developing agreements with Latin American in general and with Mercosur in particular. It is also possible that the Commission would use trade agreements in order to gain the support of the Council and, in doing so, achieve its own particular goals - such as increasing the Commission's power to negotiate agreements with third parties. On the other hand, it is also possible that the Commission was following not just its own agenda, but was in fact promoting Mercosur's agenda.

It also seems that - depending on the sensitivity of the topic, for example, agriculture - the Council will seek to have more power than the Commission. However, if the issue is somewhat less sensitive - for example, the issue of cooperation with a region like Latin America - then the Council tends to be more likely to give the Commission more autonomy to negotiate agreements and policies.

\section{Qualified majority voting}

By the 1980s, the EU consisted of twelve member states. With a view to increasing the number of decisions accepted avoiding vetos, the Single European Act (1986) started to introduce changes such as QMV in relation to issues such as trade in goods. With each enlargement of the EU, more 
countries are involved and as a result, the level of power held by each individual member state is diluted. However, due to the fact that mixed agreements are very common and they require ratification by each government, the QMV rule is less relevant in relation to issues of cooperation and association agreements. According to Aggarwal and Fogarty (2004), QMV works in favour of those countries which are more pro-free trade than those countries who favour a more protectionist position. However, 'the prevailing status of unanimity vis-à-vis QMV shapes trade policy by determining the extent to which interest groups and member governments have the scope to bend voting outcomes in the Council to their will - whether towards free trade or protectionism' (Aggarwal and Fogarty 2004).

It has already been noted that association agreements tend to be offered to preferred partners. Association agreements are considered to be more important than trade and cooperation agreements. Over the course of the last few years, association agreements have become increasingly common.

Articles 310, 133 (ex 113), 130W and 300 (ex 228(3)) relate to different areas of the decision-making process. Wessels (1997) outlines the following:

- Article 310 (ex 238): according to the EEC Treaty, association requires unanimity in the Council and in the EP assent with absolute majority of members;

- Article 133 (ex 113(3)): according to the EEC Treaty, trade agreements require a qualified majority from the Council and there is not active participation of the EP;

- Article 130W: according to the Maastricht Treaty, development cooperation requires a qualified majority from the Council and cooperation $189 \mathrm{c}$ from the EP;

- Article 300 (ex 228(3)): according to the Maastricht Treaty, agreements with third countries require a qualified majority from the Council and a simple majority of votes cast from the EP.

Regarding the process of reaching an agreement with Mercosur, the EU pointed out that although there were three areas which had to be negotiated - trade, cooperation and political dialogue - no individual agreements would be reached until agreements had been reached for all three areas. The interconnection of the three areas implies that there would be higher levels of interaction between negotiators from the Commission and from the member states.

\section{EU institutions}

Now that the 'what' and 'how' of the EU policy process has been explained, it is essential to explain issues related to 'who'. There are several actors 
from various $\mathrm{EU}$ institutions that are involved in the development of $\mathrm{EU}$ trade policy, such as the Commission, the Council of Ministers and the EP. This section aims to analyse how these different institutions interact. Here the discussion will focus on how much room each institution has for manoeuvre in terms of their powers and the role they play in the development of trade, cooperation and association agreements. The debate will be framed in terms of who has the most power. It has already been suggested that the Council is the most powerful of all the EU institutions (for example, see Westlake 1995; Cini 1996; Hayes-Renshaw and Wallace 1997; Thomson and Hosli 2004; Schalk et al. 2007). However, this is contested by Meunier (2000), who claims that the Council is the central institution in this policy process because it manages to aggregate the preferences of the member states, whilst the Commission is responsible for acting as the negotiating agent of the Council. In addition to this, Thomson and Hosli (2004) contend that there is also a perception that the Commission and the EP have more power than they really have.

The most important relationship in terms of policy development is that between the Council and the Commission. This is due to the fact that these two EU institutions are more involved in the process of policy development than other EU institutions. The power balance between the Commission and the Council is not the most settled (Nugent 2003). On the one hand, the Council tries to control the Commission. On the other hand, the Commission tries to play its role in the development of policy by gaining as much autonomy from the Council as possible (Nugent 2003). On occasion this can produce negative outcomes for the EU, particularly when negotiating with third parties. Paemen and Bensch (1995) suggest that there are three problems in the policy process: firstly, the so-called 'lowest common denominator', as the way the EU agrees on issues in its internal negotiations, takes power away from the EU; secondly, because internal EU negotiations are conducted in public they can give information to third parties about the various positions being adopted within the EU; thirdly, the control of the Council versus the Commission does not allow the Commission negotiators to take instant decisions. In reference to this third point raised by Paemen and Bensch (1995), the Council can slow the momentum of negotiations when there is difficulty in terms of developing a clear and coherent position in relation to a particular policy.

Leaving aside the issue of which EU institution is the most powerful for the moment, there are additional issues related to how the Commission and the Council manage to exercise power. It is crucial that this is understood if we are to comprehend how the EU develops trade policies. Understanding the relative power of the Council, Commission and EP is useful for this (Thomson and Hosli 2004). The Commission, being in charge of developing and putting forward draft proposals, is able to influence the content of 
proposals. However, these proposals can also be amended by the Council. According to Nugent (1999), the Commission tried to expand its power under Article 133 by citing the changes in EU trade that have occurred since the Treaty of Rome was introduced in 1957. It could be said that the Commission has tried to develop as many negotiations as possible in order to expand its levels of influence both inside and outside the EU (Aggarwal and Fogarty 2004). Aggarwal and Fogarty also suggest that the Commission tries to exert its influence by having a close relationship with interest groups which will participate in the development of EU policies. According to Thomson and Hosli (2004), research has been done on the procedural rules in terms of the opportunities or obstacles faced by institutions and the different outcomes they produced. Thomson and Hosli claim that this is due to the different ways that procedural rules have been interpreted. Therefore, even when informal institutions are included in the analysis of the balance of power between the Commission, the Council and EP, different conclusions have been drawn (Thomson and Hosli 2004). In addition to this, the power/role of informal institutions must be considered if we are to understand the different levels of power held by different actors within the context of EU policy development (Thomson and Hosli 2004).

\section{The European Commission}

The Commission is the institution that deals with most of the day-to-day trade relations with third parties. In other words, the Commission is the 'face' of the EU when third parties deal with the EU on a frequent basis (Smith 2003). The internal organization of the Commission has changed over time. There are also different directorate generals which can intervene in international trade issues. For example, there is a directorate general responsible for external relations which works closely with the high representative of the common foreign and security policy since it was created in 2003 following the Treaty of Nice. This is yet another reason why the Commission and the Council have to work closely to make international agreements possible. With regard to the Council's relationship with the Commission, it can be said that, over time, the Commission has developed more political influence, especially during the Delors Commission (Aggarwal and Fogarty 2004). This had an effect on the balance of power within the EU. For example, the presidents of the Commission can produce key changes in the EU general integration project, as well as providing more power to the Commission. Furthermore, a strong president can lead to a stronger, more unified Commission. However, this does not necessarily result in members of the Commission having or sharing a united policy agenda (Nugent 2003; Aggarwal and Fogarty 2004). The Commission is composed of different commissioners and director generals which intervene to varying degrees in the development of international agreements. These 
commissioners and director generals may indeed have their own individual agendas and aims, shaped by the specific national interests of the country which they represent (Aggarwal and Fogarty 2004).

Individual commissioners can also have their own particular reasons for the way that they try to influence agenda-setting. For example, a commissioner could have his or her own personal political ambition which has led them to bring a certain issue or policy to the table (Peters 2001). National pressure could also be a reason why an individual commissioner may give special emphasis to a particular policy (Peters 2001). The informal rule of commissioners supporting each other's ideas and portfolios in front of other institutions or in the general public domain is another feature of the way the commissioners highlight certain issues when trying to set the policymaking agenda (Christiansen 2001). In order to bring those issues to the fore, the Commission relies upon expert knowledge on many different issues (Christiansen 2001; Smith 2006), whilst being aware of the political nature of trying to influence agenda-setting. It is not an easy task for the Commission to influence the policy-making agenda when it does not have sufficient resources to do so (Christiansen 2001). This is further complicated by issues such as access to administrative expertise and political preference (Christiansen 2001).

The question of national interest also has to be carefully considered in an institution where European and not national vision has been established on the remit of civil servants. However, on some occasions this is not always the case. For example, Bellier argues that

In 1992-3 few Spanish firms were selected in the tendering procedures of DG VIII (Co-operation and Development), in contrast to British, German, French, and Italian firms, all coming from countries marked as former colonial powers. Thanks to the commissioner in charge of this sector, the Spanish set about extending Community co-operation to Latin American countries, a shift which fuelled the debate on the philosophy of development aid. (Bellier 1997: 108)

This brought into the open the question of whether national biases, promoted by the nationalities of those responsible for calls for tender, were the cause of a weakness, known in Euro-jargon as the 'rate of return'. This is calculated in relation to member states' financial contribution to a particular budget line, in this case the European Development Fund. According to Commission officials and the Spanish Secretariat of State for European Affairs, enquiries showed that Spanish firms, cushioned by their national markets in the run-up to the Olympic Games and the World Fair, were not competitive (Bellier 1997: 108).

\section{The Council of Ministers}

The different Councils are composed of different ministers emanating from the respective member states in charge of a particular area. In the case of 
EU external relations, the General Affairs Council was created in 2002 by the European Council in order to increase cohesion. When it comes to international agreements, the different enlargements have contributed to different countries bringing very varied ideas to the table. This is something that can be seen in discussions in the Council. For example, Nugent (2003) contends that countries such as Spain, Italy and France are more protectionist than the UK, whilst countries such as the Netherlands, Denmark, Finland and Germany have a somewhat ambiguous position (Woolcock 2005: 390). According to Woolcock this can be dependent upon the topic under discussion. For example, 'Ireland is liberal on trade in manufacturing, investment, but protectionist on agriculture ... Germany is liberal on trade in goods, but less so on the liberalization of agricultural or services' (Woolcock 2005: 390).

In terms of enlargement, when it became a member of the EU in 1973, the UK came to the table with a very liberal view. In contrast, when the Iberian countries became members of the EU in 1986, Spain and Portugal came to the table advocating a more protectionist agenda (Woolcock 2005). This was further complicated when the Nordic countries became members of the EU in 1995, although this was somewhat neutralized when the EU enlarged further in 2004. More specifically, the countries that joined in 2004 tended to advocate a less liberal position compared to the Nordic countries (Woolcock 2005). Therefore, it can be argued that the more countries that have joined the EU the more complicated it has become to develop a clear and coherent policy agenda (Woolcock 2005). Finally, special interest has been identified by sectors. More specifically, EU trade policy is affected by those interests, and the work of lobby groups in the area of business or agriculture is important because they are strongly organized and are able to exert pressure at both the national and supranational (Commission) level (Woolcock 2005).

\section{Other sources of power}

A way of achieving extra power within the EU is when a member state holds the presidency of the EU. The presidency of the Council is based on a rotational system whereby member states take turns in holding the EU presidency for six-month periods. The Council also needs to be represented when interacting with the other institutions and organizations such as the media or bodies outside the EU. In part, this was why the presidency was created (Westlake and Galloway 2004). The EU presidency has a wide remit. For example, the president of the EU is 'at one and the same time manager, promoter of political initiatives, package-broker, honest broker, representative to and from the other Community institutions, spokesman for the Council and for the Union, and an international actor' (Westlake and Galloway 2004: 46). In sum, the EU president has many responsibilities 
without having a great deal of power (Westlake and Galloway 2004). In EU foreign affairs, the president of the Council plays a key role. This has had a significant impact in terms of dealing with other institutions in relation to external issues. Helen Wallace contends that 'Often the Council and the Commission presidencies have to work closely together, for example in external negotiations where policy powers are divided between the EU and the national levels' (Wallace 2000: 19).

Wallace also demonstrates that the Commission and the presidency have a close and interactive relationship. The level of interdependence is also related to the country that holds the presidency, further complicated by the fact that each country has different needs, agendas or approaches (Johnston 1994). For example, older and larger powerful member states might not need so much interaction since they are used to holding the presidency and have the resources to carry out this role more effectively and also produce more coherent and popular proposals in contrast to the Commission. The different interests of the country that is holding the presidency are also reflected, letting the Commission be more or less active, depending on whether it is in favour of the country holding the presidency (Johnston 1994).

Since the president is responsible for preparing the agenda for the meetings of ministers, there is a fear that the presidency could be used to promote national interests rather than European interests. Wallace argues that:

In the legislative field it is the Council and EP presidencies that have to work together to reconcile Council and parliamentary legislative amendments. A recurrent question is how far individual governments try to impose their national preferences during the presidency or whether the experience pushes them towards identifying with collective EU interests. (Wallace 2000: 19)

Although, the country holding the presidency is expected to be impartial (Talberg 2006 cited in Schalk et al. 2007), holding this position can impart some extra influence. The role is particularly important for smaller EU member states (Smith 2003), and the extra influence that can be gained is useful in terms of developing the policy agenda and also in having access to information (Warntjen 2008). However, the pressure that these countries face from other member states can often lead to the smaller member states making concessions (Warntjen 2008). The president, in theory, is supposed to be able to broker deals and facilitate negotiations, which is the opposite of being able to use this position in order to pursue specific national interests. Some authors also contend that countries holding the presidency have a low success rate in terms of pursuing their own domestic agendas (for example, Cini 1996; Hayes-Renshaw and Wallace 1997). In contrast, others consider holding the presidency to be an opportunity to influence decision-making (for example, see Westlake 1995; Peterson and Bomberg 1999). In addition, it is also argued that the stage of policy development 
determines whether the president is able to have any influence, it being more beneficial to receive the policy at the voting stage instead of at the beginning of the policy (Schalk et al. 2007).

As far as EU-Mercosur relations are concerned, arguably the most important moment in the development of this relationship occurred during the course of the Spanish and Portuguese presidencies. For example, in 1992, the first cooperation agreement was negotiated and agreed during the Portuguese presidency. In 1995 the EMIFCA was signed during the Spanish presidency. In addition to this, during the course of the Spanish presidency in 2002 a final calendar was agreed in terms of developing EU-Mercosur relations, and in 2004, during the Portuguese presidency, the negotiations between the EU and Mercosur were planned to end. During the Spanish presidency of 2010 the negotiations were launched again.

\section{Conclusion}

This chapter has discussed many of the different aspects that need to be considered when examining the development of EU policy-making towards Mercosur. It has demonstrated that the political process within the EU involves different delegations of power which can have varying degrees of impact at different points during the course of the three distinct stages of policy development. In this sense, the delegation of power from the Council to the Commission was necessary in order to develop policies which Mercosur had officially started in the second stage (1991-1995).

Different agreements between the EU and Mercosur have to be negotiated within different legal frameworks. This suggests that there are different processes in terms of decision-making in the course of policy development. This is particularly relevant in relation to developing the association agreement between the EU and Mercosur, which required unanimous support from the Council. This left little room for disagreements between EU member states. Having outlined the institutional structure of the EU, I have shown that the Commission and the member states are the main actors involved in shaping EU policy towards Mercosur. Attention will now turn to the first of three empirical chapters that will examine the noninstitutionalized relation of the EU and Mercosur between 1985 and 1990. 